\title{
A FRAMEWORK FOR USE OF ADJUNCT FACULTY IN TEACHING SCHOOLS
}

\author{
Ganesh Vaidyanathan, Roosevelt University, gvaidyanathan@roosevelt.edu \\ Asghar Sabbaghi, Roosevelt University, asabbaghi@roosevelt.edu
}

\begin{abstract}
Adjunct faculty have the potential to contribute significantly to a school's mission in sharing their professional experience and experiential education, and to enhance the partnership with the business community. They complement full-time faculty who may focus on their scholarship in meeting scholarly academic qualifications of the faculty resources. Adjuncts seem to have more practical knowledge and teaching schools seem to have students who are attending for "practical" experiential based education. Many business schools, particularly in more urban areas, are heavily dependent on business community professionals as adjunct faculty resources. The faculty research, particularly in small colleges, may focus more on pedagogical, disciplined based and applied scholarship. Business schools deliberately hire practitioners to teach specific courses and highly value their contributions. However, accreditation bodies such as AACSB International have made it clear how and when adjuncts should be deployed in business schools. How can business schools in general effectively use adjunct faculty?
\end{abstract}

Keywords: Adjunct faculty, AACSB standards, efficient use, framework

\section{INTRODUCTION}

The Association to Advance Collegiate Schools of Business (AACSB) is considered as the gold standard for businessschool accreditation. The Association of MBA (AMBA) and the European Foundation for Management Development's International Accreditation Program (EQUIS) view that AACSB accreditation is a basic requirement to be a competitive business school (Miles, Franklin, Grimmer, \& Herriot, 2015). Because of its rigorous standards, less than $5 \%$ of the world's 13,000 business programs have earned AACSB accreditation.

In a survey, faculty members perceived accreditation beneficial to their business school, their students, and to the employers of their students but felt that the accreditation process did not help them personally. The study suggested that faculty at AACSB accredited institutions view accreditation very positively with a perception of a financially secure quality program. New faculty value research and teaching at AACSB accredited institutions and truly believe that accreditation benefits faculty, students, and employers (Roberts, Johnson, \& Groesbeck, 2006). Teaching and research are inter-related as results from research enhance teaching content. However, there appears a dichotomy in literature regarding how research impacts teaching. While a substantial body of literature show the research value of a professor's research and publishing to teaching success and effectiveness, Kasten (1984) speculated that there is a negative relationship between research and teaching. But, Bell, Frecka, \& Solomon (1993) established positive correlation between teaching effectiveness and research publications. Moreover, a study revealed that faculty in nondoctoral granting business schools perceived that their research enhance learning outcomes of their students (Taylor \& Stanton, 2009).

The old 2003 AACSB standards established that business school faculty members must develop and maintain academic qualifications by publishing in peer-reviewed quality research journals. In general, participant standards impact faculty teaching load and research expectations by demanding faculty members to sustain some level of currency in their discipline and pedagogy skills (Miles, Hazeldine, \& Munilla, 2004). But, some business schools, especially teaching schools, had to hire adjunct professors to balance faculty teaching loads and cost constraints. While the share of full, associate and assistant professors has stayed flat or declined since 2008, adjuncts are taking a larger chunk of the employment pie (Gillespie, 2014).

The current 2013 AACSB Standard 5 directs two categories of appropriately qualified faculty members that includes participating and supporting faculty in assessing a business school's faculty sufficiency with specifications that the two categories are determined by the member institution. To ascertain faculty sufficiency, a business school should 


\section{Issues in Information Systems \\ Volume 19, Issue 4, pp. 77-86, 2018}

ensure sufficient faculty-student interaction and effective deployment of faculty apart from research expectations (Abdelsameed, Farmer, McNeil, \& Stevens, 2015). A supplemental argument on the topic of research and teaching effectiveness seems to impact the employment of adjunct faculty. Some scholars believe that the emphasis on research has led to an "academic-practitioner divide" (Ottesen \& Gronhaug, 2004; Thomas, 2006). This academic divide has resulted in lesser role in teaching for adjunct faculty in accredited business schools. Apart from the fact that the adjunct faculty members do not conduct research, the real focus of accreditation relates to adjuncts not playing a big part in student engagement. But, the contributions of adjunct faculty towards the business school's mission can enrich the experiences of students. Meixner and Kruck (2010) have lamented that very little has been published about part-time faculty in four-year institutions and most of the research is focused on the role of the adjunct faculty in the community college system.

This paper focuses on how to include adjunct faculty in universities using the current 2013 standards. The next two sections review current literature on how adjuncts can play a role to fulfill the mission of business schools towards maintaining AACSB accreditation. The following section identifies various student learning factors and describes a framework using those factors. The final section illustrates ways to use adjunct faculty for faculty sufficiency and methods to motivate them to play an important part in AACSB accreditation.

\section{AACSB STANDARDS AND QUALITY IN EDUCATION}

A summary on the United Nations ratification of 17 Sustainable Development Goals (SDGs) proclaimed that the meaning of a Quality Education is one that is pedagogically and developmentally sound and educates the student in becoming an active and productive member of society (Slade, 2016). To make a student active and productive member of the society, a continuous improvement process in pedagogy, systems, and environment. It is also a well-known fact that quality processes require continuous improvement. In support of its commitment to continuous improvement, AACSB International (AACSB) has decided to pursue a quality assurance certification.

AACSB accreditation and quality assurance have long been synonymous with the highest standards in business education. AACSB fosters quality assurance by its standards for business schools to provide evidence of continuous improvement in three vital areas including innovation, impact, and engagement. Innovation relates to finding creative ways to produce value for students, employers, and the community. Impact refers to how a high-quality business education should make a difference through both scholarly education and impactful intellectual contributions. Such impacts can be demonstrated by how the programs and students of any university make a difference to society in general. Engagement is focused on how business education that is both scholarly and relevant for practice fosters meaningful interactions among faculty, students, and business professionals. AACSB's standards emphasize the "realworld", practical, and experiential education to be a key component of a successful business education.

AACSB utilizes faculty sufficiency as a measure of student engagement. AACSB's mission is to encourage engagement, innovation, and impact in business education and validate quality business education. Engagement is to prepare students for meaningful professional, societal, and personal lives. A well-balanced academic and professional engagement should be present that is consistent with quality in the context of a school's mission. The accreditation standards pave the way for business schools to innovate and pursue continuous improvement in curriculum, programs, and other mission based activities. AACSB accreditation also focuses on the impact of its quality inputs such as faculty and other resources on outcomes within the context of the school's mission (AACSB, 2017).

To ensure the quality outcomes through engagement, innovation, and impact, business schools are required to maintain and deploy faculty sufficiency (AACSB, 2017). AACSB standards expect qualified full-time faculty to deliver at least $75 \%$ of the overall business school's teaching and at least $60 \%$ by discipline, program, location, or delivery mode (AACSB, 2017: Standard 5). This is to engage students and receive instruction from appropriately qualified faculty. The qualified faculty must be defined by business schools that is consistent to their individual mission statements. The basic premise behind the requirement of academically qualified faculty is to employ faculty who can assure quality of the educational experience, demonstrate high quality creative scholarly activities and contribute positively to the mission of the business school. 


\section{ADJUNCT FACULTY IN BUSINESS EDUCATION}

Adjunct faculty members are part-time instructors who teach one or two classes. Adjuncts are less expensive than fulltime faculty and they do not receive employment benefits. There is a great deal of variation in the way business schools hire, deploy, and compensate their adjuncts. As the cost of granting tenure increased, universities have increasingly employed adjuncts. Adjunct faculty provide huge benefits for any university. Adjunct faculty members are paid less than full-time faculty as they are expected only to engage in teaching. In addition, adjunct faculty typically have industry experience and they can bring "real-world" experiences to their classes that can be highly beneficial to students. Adjuncts do not have scholarship and service requirements and can therefore specialize in teaching and be great teachers (Ehrenberg \& Zhang, 2005). They may practice consulting to bring "real-world" examples to their classes. Adjuncts often have a small, positive effect on enrollment patterns, especially in fields related to certain occupations (Bettinger, \& Long, 2005; Bettinger \& Long, 2010).

Adjuncts have been criticized that they cannot provide the same quality of education mainly due to the lack of their doctoral degrees, and universities with a greater reliance on adjuncts tend to have a higher dropout rate. Since adjunct teachers do not spend time on scholarship activities and as research influences teaching quality, adjuncts may not be perceived as effective teachers as full-time faculty. They cannot provide advice on research opportunities and prepare students for graduate-level education (Ehrenberg \& Zhang, 2005). They can present serious problems such as lack of pedagogical skills. Moreover, adjunct faculty in many cases are not advised or aware of the outcomes and objectives (Gerhart, 2004). Androniceanu (2014) observed that adjunct faculty either may not have many options in course preparation and usually lecture beyond their expertise or restricted themselves to adhere to obsolete, ill-conceived, or substandard syllabi. Since many of the adjuncts may teach in several colleges and universities, their commuting time may leave not much time to focus on classes substantially. Most of the adjunct faculty work in industrial organizations or in multiple universities. Moreover, most adjuncts do not have an office, no locked storage for their materials, commitment or adequate technology. Such environments prevent their availability to students outside of the classroom and present a problem to their students (Edmonds, 2015). Adjuncts may rely heavily upon positive student teaching evaluations to retain their jobs that may impact both the rigor of instruction provided as well as possible grade inflation (Sonner, 2000). Some critics contend that adjuncts reduce educational quality since they do not have doctoral degrees (Bettinger \& Long, 2010). The same study suggested that adjuncts adversely affect student dropout rates and established that taking courses from full-time faculty members is important for student retention (Bettinger \& Long, 2010).

However, many studies have remarked that adjunct faculty are motivated teachers. Adjunct faculty can and do provide a positive impact on student learning. Feldman and Turnley (2001) demonstrated that adjunct faculty late in their career exhibited more positive job attitudes and work behaviors than adjunct faculty in earlier career stages. Mueller, Mandernach, \& Sanderson (2013) state that online students report that the real-world, applied expertise of adjunct faculty, along with their evening/weekend availability, are more amenable to student expectations. They cite that online students really like and want adjunct faculty who are actively working in the real world.

\section{A FRAMEWORK OF ENGAGEMENT AND IMPACT}

Typically, business schools adopt the concept of participating and supporting faculty to adhere to AACSB standards on faculty sufficiency. Participating Faculty (PF) are typically defined as those members who engage in classroom teaching and actively participate in the intellectual and operational activities that are essential in achieving the mission of a business school. Supporting Faculty (SF) are typically the faculty members whose main responsibility is teaching. In general, all tenure or tenure-track faculty members can be considered as participating faculty.

A business school applies certain criteria that are consistent with its mission to document faculty members as either participating or supporting faculty. AACSB standards provide certain guidelines for faculty sufficiency. A business school can adapt this guidance to satisfy its mission by developing and implementing criteria that specify required activities to attain and maintain participating status. The activities where faculty exhibit sufficiency to ensure achievement of the mission of the business school should involve quality, impactful contributions to education, research, and service. Such activities need to expose impact of outcomes based on the mission of the business school. Those activities need to reflect the quality of engagement with respect to students, faculty, and community. 


\section{Issues in Information Systems}

Volume 19, Issue 4, pp. 77-86, 2018

Engagement can be defined as "the collaboration between institutions of higher education and their larger communities (local, regional/state, national, global) for the mutually beneficial exchange of knowledge and resources in a context of partnership and reciprocity" (Driscoll, 2008, p. 39). In business schools, the impact of engagement should be deeply rooted within the teaching, research, and service missions. Fizgerald, Bruns, Sonka, Furco, \& Swanson (2016) elaborate engagement to accomplish the following:

- Enrich learning experience for students,

- Support a curriculum that improves student development,

- Help universities to meet return on investment and to demonstrate accountability,

- Improve relationships between universities and their communities,

- Improve research of greater impact and relevance,

- Advance research opportunities,

- Encourage innovative practices for researchers, and

- Stimulate creativity and innovation.

Stanton (2008) established other facets to engagement such as:

- Improve quality of life of communities by service by cultivating relationships;

- Collaborate with communities to enhance community assets;

- Encourage service-learning, professional service, and public work;

- Provide opportunities for students to develop civic competencies and habits;

- Promote student civic engagements; and

- Create and sustain community-focused culture.

Milburn-Shaw and Walker (2017) argued that student engagement must incorporate elements including the student's will to learn, a pedagogical approach centered on critical thinking and independent thought, genuine and continuous debate, participation, and critical thinking, activities beyond classroom activities and academic assessments, student participation in student groups and societies, and engaged learning through projects.

From the research literature cited in the above paragraphs, such activities to achieve the mission of a business school can be classified as three categories including:

- Governance engagement activities;

- Curricular engagement activities; and

- $\quad$ Student engagement activities.

\section{Governance engagement activities}

Governance in universities includes several different faculty and student bodies working together through standardized processes to make decisions. Faculty advise administration in tenure appointments and the award of promotion and sabbatical. Faculty members get involved in establishing various procedures for example, awarding promotions, sabbaticals, research support, rewards, and every part of faculty development issues, and faculty governance processes. Such governance activities are a regular part of the professional duties of faculty. Faculty members form committees and meet often to make decision and recommendations. Committee work for departments, college, university, and university senate are common governance engagement activities in universities. Committees and taskforces consisting of faculty members actively involve in strategic planning at various levels of their institutions. Some faculty members are active in the governance of academic and professional organizations as well. An advisory board is typically a group of professionals brought together to help an academic center to pursue and accomplish its mission (Akers \& Giacomino, 2004). Several business schools make use of their advisory board members to work as adjunct faculty to supplement teaching requirements.

\section{Curricular engagement activities}

As part of curricular engagement, faculty is responsible for establishing degree requirements, reviewing text books for adoption in classes. Faculty are responsible for curricula development and course changes. Since many business schools employ advisory board members who are in high positions in industrial organizations, the advisory board members can collaborate with faculty to help them in their curricula changes to suit current industrial needs. They can be of help to connect faculty with other companies to understand what industries need in the future and help direct 


\section{Issues in Information Systems}

Volume 19, Issue 4, pp. 77-86, 2018

faculty in their research. Faculty members attend symposiums, seminars, and conferences to understand new teaching methods and to enhance their teaching skills.

AACSB's Assurance of Learning (AoL) standards ensure that business schools set student learning goals, assess student achievement of those goals, and address the disparity between the goals and student achievement. The AoL features learning goals and require teaching faculty to collect the outcomes of those learning goals to be used for continuous improvement of student learning and development. The faculty of AACSB accredited business schools develop such processes to ensure the facilitation of continuous improvement in student learning outcome. The faculty design and develop methods to measure student learning. AoL reinforces the accountability facet of high quality business programs by ensuring the delivery of high quality curricula and assessing student learning to support curricula improvements. Adjunct faculty can help business schools in their curricular engagements.

\section{Student Engagement}

AACSB standards require business schools to demonstrate interactions between faculty, students, administrators, and staff. Business schools must utilize sufficient, qualified, and engaged faculty to conform to their mission. The main idea is to institute appropriate processes for active student involvement to maintain high quality results in student learning outcome (Trapnell, 2007). Student engagement is the focal point for business education based on its relationship with student learning outcomes. Business faculty members must find ways to measure student engagement to demonstrate quality (Burch, Heller, Burch, Freed, \& Steed, 2015). In the same paper, they hypothesized that student engagement consisted of four factors including emotional engagement, physically engagement, cognitive engagement in class and cognitive engagement out of class. The emotional engagement is related to students who are interested and excited to attend class and perform assignments. The physical engagement refers to the energy and effort of students to complete assignments and attend class. The in-class cognitive engagement is based on the attention and focus of students. The cognitive out of class engagement is towards attention and focus when studying class material. These four types of student engagement rest entirely upon the environment created by the instructor. With respect to cognitive engagement, a study explored instructional differences between full-time and part-time faculty and indicated that part-time faculty evidenced neither a weaker instructional capacity nor less overall rigor in their grading (Eisenberg \& Zhang, 2004). Afjunct faculty accomplish their student engagement with little institutional support such as offices or other university-sponsored faculty development activities. Eisenberg and Zhang (2004) found that graduation rates decreased when students were taught by part-time and full-time nontenure-track faculty. However, student engagement lacks an agreed definition and is often defined in ambiguous terms (Milburn-Shaw \& Walker, 2017).

Adjunct faculty can help business schools in their quest to accomplish their mission in many ways. They can typically review projects, mentor students, review resumes of students, and help students to get better professional employment by mentoring them through mock interviews. They can supervise internships and field projects as part of student experiential education. Adjuncts faculty with connection to industrial organizations can attend career fairs, job fairs, and other student networking events to motivate students. One of the many ways to motivate students is to provide advice and mentor them to accomplish the mission of their schools.

\section{Engagement and Impact}

High-impact practices by faculty suggest increase rates of student retention and student engagement (Kuh, 2008). Tinto (1993) designed a model that proposed that the decisions of students to persist or withdraw from college depend heavily on their successful academic and social integration within the college. In other words, the impact of student retention relied heavily on faculty engagement and interactions at various levels. For example, adjunct faculty can create value by incorporating relevant and real-world learning into student experiences. This kind of experiential education can provide significant learning experiences for students and offer an innovative, engaging, and impactful curriculum. The adjuncts, since they can bring in the real-world experiences to the class, can be a big part of an impactful curriculum and student engagement in class and outside the class.

For the above activities to fulfill the mission of the business school, the activities should exhibit impactful outcomes. Using the impact of outcomes from various engagement activities, a framework can be created. The value of impact of such engagement activities may be determined using a 5-point Likert scale that includes very high impact, above average impact, average impact, below average impact, and very low impact. The framework is shown in Figure 1. 


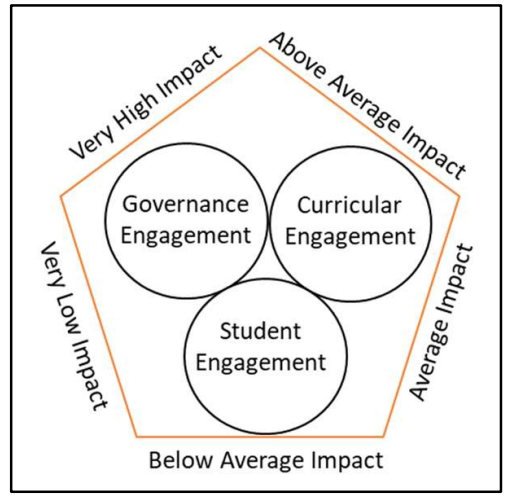

Figure 1. Framework of Engagement and Impact

A comprehensive list of faculty engagement that can be gathered from the above research studies includes the following activities. Suggested impacts associated with those activities are also provided in the following table.

Table 1. Impact of Engagement Activities

\begin{tabular}{|c|c|}
\hline Engagement Activity & Impact \\
\hline \multicolumn{2}{|l|}{ Governance Engagement } \\
\hline Participates regularly in department meetings & Average impact \\
\hline Participates regularly in school meetings & Average impact \\
\hline Participates regularly in university level meetings & Average impact \\
\hline Participates in committee work & Average impact \\
\hline Chairs a committee & Very high impact \\
\hline Participates in department advisory boards meetings & Very high impact \\
\hline Actively involves in strategic planning at department, school, and/or at university level & Very High impact \\
\hline Participates actively in academic and/or professional organizations & Very High impact \\
\hline \multicolumn{2}{|l|}{ Curricular Engagement } \\
\hline Reviews texts/cases for adoption in class & Above average impact \\
\hline Collaborates with other faculty on course changes/development & Above average impact \\
\hline Connects school with businesses/organizations for curricula changes & Above average impact \\
\hline Works with businesses/organizations for innovative and futuristic curricula changes & Very high impact \\
\hline $\begin{array}{l}\text { Participates in Assurance of Learning (AoL) activities such as rubrics reporting/outcome } \\
\text { assessments }\end{array}$ & Very high impact \\
\hline Participates in Redesigning/Designing new courses based on AoL "closing-the-loop" & Very high impact \\
\hline Designs new courses that fit the mission of the school & Very high impact \\
\hline Creates or applies pedagogy-related material & Above average impact \\
\hline Attends academic symposiums and conferences & Below average impact \\
\hline \multicolumn{2}{|l|}{ Student Engagement } \\
\hline Reviews student projects (not students in their own class) as part of outcome assessment & Above average impact \\
\hline Supervises student internships & Above average impact \\
\hline Supervises student field projects & Very high impact \\
\hline Mentors student(s) academic progress & Above average impact \\
\hline Reviews resumes and/or participates in practice interviews & Average impact \\
\hline Attends student networking events (i.e. career fairs and job fairs) & Below average impact \\
\hline Presents or participates in panel discussions in student organized activities & Very high impact \\
\hline Advises student organizations and programs & Very high impact \\
\hline Facilitates job shadowing opportunity for students & Very high impact \\
\hline Serves as a coach or judge in student competitions & Very high impact \\
\hline Attends graduations, award banquets, receptions, and any similar events & Average impact \\
\hline
\end{tabular}




\section{Issues in Information Systems}

Volume 19, Issue 4, pp. 77-86, 2018

\section{EFFECTIVE USE OF ADJUNCT FACULTY}

When addressing high volume, lower level classes, institutions resort to standardized courses. The scope and depth of such standardized courses must be managed as well as curricular integrity must be preserved. Though there exists criticisms of academic freedom and negative effects of creativity and innovation, Puzziferro and Shelton (2008) argue that there exists a midpoint and can be achieved with the involvement of both full-time and adjunct faculty who teach such sections. The core faculty can lead the content creations and delivery assisted by the adjuncts thereby empowering the faculty to update and modify the course based on assessments. The adjuncts provided with such standardized course objectives, syllabus, and course outcomes will prove to be effective in courses with multiple sections. Adjunct faculty, particularly in small private institutions, can contribute to course delivery, instruction, and student mentoring (Stenerson, Blanchard, Fassiotto, Hernandez, \& Muth, 2010).

Lyons (2007) summarized that adjuncts require adequate training in teaching and classroom management skills, professional development, a thorough orientation to the institution, its culture and practices, and above all, a recognition for their quality work. The author cites that in the University of Central Florida with about 300 adjuncts achieved good results by employing a three-pronged delivery system consisting of a series of workshop sessions, a day-long retreat, and an online program. Adjuncts should be trained in teaching techniques and methods to fully understand the classroom environment and learning styles of various students. Adjunct faculty can apply their current practical knowledge to the classroom, but they should be trained in how to prepare and deliver the content to the students. Adjunct faculty should be trained in the mission and values of the institution to ensure their teaching adequately represents and conveys that university's mission (Dailey-Hebert, Mandernach, Donnelli-Sallee \& Norris, 2014). Mueller et al. (2013) reflected that the effectiveness of online adjunct faculty may be enhanced through dedicated attention to fostering an integrated faculty body, implementing targeted faculty development programming, enhancing communication, and examining institutional policies.

Green (2007) states that it is very important for adjunct faculty to understand student outcomes. The author proposes that course objectives should include appropriate assessment and feedback. Business schools should encourage and help adjuncts to implement timely, meaningful assessment and feedback. A good feedback mechanism to ensure effective teaching and coverage of all topics required in the course should be used by universities. The adjuncts bring the latest expertise to the classroom and they can be effective mentors and models to students (Stenerson et al., 2010). Adjuncts should be encouraged to participate in outside the class activities such as mentoring and other student engagement activities.

Ciabocchi, Ginsberg, \& Picciano (2016) compared online, hybrid, and face-to-face classes by traditional and adjunct faculty. They found no statistically significant differences on student performance and in fact, the study supported minimal differences in student learning outcomes across the instructional formats. Adams \& Dority (2005) supports adjunct faculty members who are skilled in online teaching to assist with teaching online and hybrid courses, academic advising, and office hours that extend beyond the traditional hours.

\section{CONCLUSION}

AACSB modified the standards to include the adoption of faculty sufficiency model that incorporated participating faculty (PF) and supporting faculty (SF). The value of AACSB accreditation may vary based on the mission and the size of a business school. Tullis and Camey (2007) state that smaller regional and private schools may benefit the most from AACSB accreditation. AACB Standards 2013 states, "Professional engagement reflects faculty practice-oriented development activities that support integration of relevant, current practice of business and management consistent with the school's mission, expected outcomes, and supporting strategies." Adjunct faculty can effectively serve this purpose when there is a well-developed process for hiring, mentoring, and evaluation.

Adjunct faculty have the potential to contribute significantly to a school's mission by sharing their professional experience both in class and in student experiential education and to enhance the partnership with the business community. Adjuncts seem to have more practical knowledge and teaching schools seem to have students who are attending for "practical" experiential based education. This paper illustrates how adjuncts can play a role to fulfill the mission of business schools towards maintaining AACSB accreditation. We believe that there must be a strong 


\section{Issues in Information Systems}

Volume 19, Issue 4, pp. 77-86, 2018

alignment and integration between full-time and adjunct faculty as they complement each other to gain synergy of these resources. This in turn would requires more commitment on training department chairs who hire and oversee the adjunct faculty and make the course assignments so that they learn to apply the best practices in deploying their adjuncts and integrating them into the curriculum and the school. We present a framework using the impact of outcomes from various engagement activities. In fact, to make the best of resources, business schools need to view the adjunct faculty as an integral part of the faculty community and connect them with the full-time faculty and the school governance so that they feel like they are part of the same institution and ownership. They must be integrated into the mission, strategy and the future of the school. This framework would bring much richness to the school and to students' academic and professional career success.

\section{REFERENCES}

AACSB (2017). Eligibility Procedures and Accreditation Standards for Business Accreditation. Tampa, FL.: AACSB International.

Abdelsamad, M. H., Farmer, B., McNeil, R., \& Stevens, G. E. (2015). Major changes in AACSB standards (2003 compared to 2013). SAM Advanced Management Journal, 80(3), 4-11.

Adams, M. \& Dority, K. (2005). Part-Time Faculty: Building a Quality Team. Distance Education and Training Council, 24, 1-48.

Akers, M., \& Giacomino, D. 2004. Boards of advisors in small businesses: An empirical profile of their composition and use. Journal of Business \& Economics Research, 2(6), 27-35.

Androniceanu, A. (2014). Research on management capacity of medical units for addicts to deliver quality services in time of crisis. Revista de Cercetare si Interventie Sociala, 47, 78-104.

Bell, T. B., Frecka, T. J., \& Solomon, I. (1993). The relation between research productivity and teaching effectiveness: empirical evidence for accounting educators. Accounting Horizons, 7(4), 33.

Bettinger, E. P., \& Long, B. T. (2010). Does Cheaper Mean Better? The Impact of Using Adjunct Instructors on Student Outcomes. Review of Economics and Statistics, 92(3), 598-613.

Bettinger, E., \& Long, T. L. (2005). Help or hinder? Adjunct professors and student outcomes. Ithaca, NY: Cornell University.

Burch, G. F., Heller, N. A., Burch, J. J., Freed, R., \& Steed, S.A. (2015). Student Engagement: Developing a Conceptual Framework and Survey Instrument. Journal of Education for Business, 90, 224-229.

Chapman, B. F., \& Henderson, R. G. (2010). E-learning quality assurance: A perspective of business teacher educators and distance learning coordinators. The Journal of Research in Business Education, 52(1), 16.

Ciabocchi, E., Ginsberg, A., \& Picciano, A. (2016). A Study of Faculty Governance Leaders' Perceptions of Online and Blended Learning. Online Learning, 20(3), 52-73.

Dailey-Hebert, A., Mandernach, B. J., Donnelli-Sallee, E., \& Norris, V. R. (2014). Expectations, motivations, and barriers to professional development: Perspectives from adjunct instructors teaching online. Journal of Faculty Development, 28, 67-82.

Driscoll, A. (2008). Carnegie's community-engagement classification: Intentions and insights. Change, 39-41.

Edmonds, D. (2015). More than half of college faculty are adjuncts: Should you care? Forbes, May 28, 2015. 


\section{Issues in Information Systems}

Volume 19, Issue 4, pp. 77-86, 2018

Ehrenberg, R. G., \& Zhang, L. (2005). Do tenured and tenure-track faculty matter? Journal of Human Resources, $40(3), 647-659$.

Feldman, D. C., \& Turnley, W. H. (2001). A field study of adjunct faculty: The impact of career stage on reactions to non-tenure-track jobs. Journal of Career Development, 28(1), 1-16.

Fitzgerald, H. E., Bruns, K., Sonka, S. T., Furco, A., \& Swanson, L. (2016). The centrality of engagement in higher education. Journal of Higher Education outreach and engagement, 20(1), 223-244.

Gerhart, A. L. (2004). Adjunct and temporary faculty-advantageous or detrimental? Phi Kappa Phi Journal, 84(4), 21.

Gillespie, P. (2014). Business schools are on a hiring spree. Journal of Higher Education outreach and engagement, $20(1), 223-244$.

Green, D. W. (2007). Adjunct faculty and the continuing quest for quality. New directions for community colleges, 140, 29-39.

Kasten, K. L. (1984). Tenure and merit pay as rewards for research, teaching, and service at a research university. The Journal of Higher Education, 55(4), 500-514.

Kuh, G. (2008). High-impact educational practices. Washington: Association of American Colleges and Universities.

Lyons, R. (2007). Deepening our understanding of adjunct faculty. In R. Lyons (Ed.), Best practices for supporting adjunct faculty, Bolton, MA: Anker Publishing.

Meixner, C., \& Kruck, S, E. (2010). Inclusion of Part-Time Faculty for the Benefit of Faculty and Students. College Teaching, 58(4), 141-147.

Milburn-Shaw, H., \& Walker, D. (2017). The politics of student engagement. Politics, 37(1), 52-66.

Miles, M. P., Franklin, G. M., Grimmer, M., \& Heriot, K. C. (2015). An exploratory study of the perceptions of AACSB International's 2013 Accreditation Standards. Journal of International Education in Business, $8(1), 2-17$.

Miles, M.P., Hazeldine, M., \& Munilla, L. (2004), The 2003 AACSB Accreditation Standards and Implications for Business Faculty: A Short Note, Journal of Education for Business, 80(1), 29-34.

Mueller, B., Mandernach, B. J., \& Sanderson, K. (2013). Adjunct versus full-time faculty: Comparison of student outcomes in the online classroom. Journal of online learning and teaching, 9(3), 341-347.

Ottesen, G.G. \& Gronhaug, K. (2004), Barriers to practical use of academic marketing knowledge. Marketing Intelligence and Planning, 22(5), 520-530.

Puzziferro, M., \& Shelton, K. (2008). A model for developing high-quality online courses: Integrating a systems approach with learning theory. Journal of Asynchronous Learning Networks, 12, 119-136.

Roberts, W.A., Johnson, R., \& Groesbeck, J. (2006). The perspective of faculty hired after AACSB accreditation and accreditation's' impact and importance. Academy of Educational Leadership Journal, 10(3), 59-71.

Slade, S. (2016) What Do We Mean by a Quality Education? The Huffington Post, February 22, 2016.

Sonner, B. S. (2000). A is for "adjunct": Examining grade inflation in higher education. Journal of Education for Business, 76(1), 5-8. 


\section{Issues in Information Systems}

Volume 19, Issue 4, pp. 77-86, 2018

Stanton, T. K. (2008). New times demand new scholarship: Opportunities and challenges for civic engagement at research universities. Education, Citizenship and Social Justice, 3(1), 19-42.

Stenerson, J., Blanchard, L., Fassiotto, M., Hernandez, M., \& Muth, A. (2010). The role of adjuncts in the professoriate. Peer Review, 12(3), 23-26.

Taylor, R.L., \& Stanton, A.D. (2009). Academic publishing ad teaching effectiveness: an attitudinal study for AACSB accredited business school faculty. Academy of Educational Leadership Journal, 13(2), 93-106.

Tinto, V. (1993). Rethinking the Causes and Cures of Student Attrition. 2nd ed., Chicago: University of Chicago Press.

Trapnell, J.E. (2007). The value proposition and a look to the future. Journal of Management Development, 26(1), 67-72.

Tullis, K.J., \& Camey, J.P. 2007. Strategic implications of specialized business school accreditation: End of the line for some business education programs? Journal of Education for Business, 83(1), 45-51. 